\title{
Germination in Vitro of Brassicaceae (Sinapis arvensis L.) in the Northern Region of Tlemcen (Algeria)
}

\author{
Benabadji Noury, Belkhodja Amal Nesrine, Abdeljalil Anissa \\ Laboratory of Ecology and Management of the Natural Ecosystems, Department of Ecology and Environment, Aboubakr Belkaid University, \\ Tlemcen, Algeria
}

Email address:

nesrine.benlaldj@yahoo.fr (B. A. Nesrine)

\section{To cite this article:}

Benabadji Noury, Belkhodja Amal Nesrine, Abdeljalil Anissa. Germination in Vitro of Brassicaceae (Sinapis arvensis L.) in the Northern Region of Tlemcen (Algeria). American Journal of Life Sciences. Vol. 3, No. 4, 2015, pp. 279-289. doi: 10.11648/j.ajls.20150304.15

\begin{abstract}
This ecophysiological study was conducted on a species (Sinapis arvensis L.) widespread in nature in Algeria particularly in the province of Tlemcen. This plant, even if it is undesirable in crop fields, can be useful in maintaining the biodiversity of the plant world. The goal set in this study was to treat the micro-propagation and germination of the species Sinapsis arvensis $\mathrm{L}$. in synthetic environments, since these phenomena of growth and development in a sterile environment are poorly controlled. Our work deals successively with the following results: - The in vitro germination of Sinapis arvensisin different synthetic media, seeds taken of pods are harvested in stations in the Tlemcen region (Zenata, Beni-Ghanam and Rachgoun stations). They germinate differently; the germination rates vary with temperature and media used (Nutrient Agar and Potatoes Dextrose Agar, distilled water with $\mathrm{NaCl}$ at different concentrations, $1 \mathrm{~g} / \mathrm{L}, 3 \mathrm{~g} / \mathrm{L}$ and $5 \mathrm{~g} / \mathrm{L}$ ). This phenological phase appears to respond positively to the experimentation multiple conditions. - The percentage of germination was $75 \%$. Contamination by pathogens reaches $25 \%$, despite the taken precautions (sterility of plant material, cleaning glassware, etc.).
\end{abstract}

Keywords: Sinapis arvensis L., Nutrient Agar, Potatoes Dextrose Agar Medium, Germination, Region of Tlemcen, Algeria

\section{Introduction}

Very effective in vitro culture remains a tool for biological and physiological research (Haicour, 2002).

Numerous studies have dealt with in vitro culture describing all used methods both in the animal and plant kingdoms (Harper and Benton, 1966; Dubey and Mall, 1972; Ungar, 1978; Koller and Hadas, 1982; Van Der Toorn and Ten Hove, 1982; Augéand al., 1989; Margara, 1989; Benchenafi and al., 2013). This is generally a method of growing plants in aseptic conditions (without fungi and bacteria) using quite complex culture media (hormones, sugars, vitamins, amino acids, mineral salts) that can be liquid, agar, or even solids with the use of vermiculite (Jay Allmand and al., 1992).

We used the variability that occurs in vitro for an efficient plant according to some defined criteria; many other useful plant substances could be produced by tissue culture (Haines, 1995).

In vitro culture helps cultivate tissues or organs fragments isolated from a plant that can regenerate shoots, but also roots. This technique also provides isolated cells or even to regenerate a whole plant. In vitro culture produces the regenerative potential of a plant, to the cell totipotency which can result following this simple formula: 1 cell/unit $=1$ whole plant (Jay-Allmand and Capelli, 1997).

Through this study we will perform an experiment (germination) with the species Sinapis arvensis, which is a Brassicaceae, and, according to Patrice (in Abddeldjelil, 2014), is considered as one of the most economically important ten plant families.

Particular attention will then be paid to the species vegetative stage, in this instance germination.

In this work, we propose to vary the seeds sampling from the representative stations. Would the seeds meet these artificial food environments? Can these environments provide the best conditions for seed germination especially those belonging to Sinapis arvensis L.?

\section{Methodology and Study Sites}

\subsection{Methodology}

\subsubsection{Disinfection of Equipment and Samples}

In vitro culture technique requires great care in 
maintaining cultures in asepsis conditions. Infections are either bacterial or fungal but these are most prevalent in the early cultures.

Disinfection of plant material is always difficult and unpredictable; the degree of infection of surface tissue is highly variable.

The disinfection method we used is the most common, which is to briefly immerse the sample in different solutions:

- Wash in running water,

- Immersion in a bleach solution,

- Three successive rinses with distilled water.

The seeds are disinfected according to the following protocol:

- Wash in running water,

- Soaking grains in ethyl alcohol at $70 \%$ for 20 to 25 seconds

- A bleach bath solution at 15 minutes,

- Three washes with distilled water at 10 minutes each.

The beads are then placed in petri dish; they are

transplanted in the culture medium with sterile pliers.

The boxes are closed to prevent contamination; all manipulations are carried out under sterile hood.

A part of the dishes was stored at laboratory temperature $\left(25^{\circ} \mathrm{C}\right)$ and another at $30^{\circ} \mathrm{C}$ and the last at $4^{\circ} \mathrm{C}$ for which we aim to test the effect of temperature on the germination.

\subsubsection{Media Composition}

The seeds are germinated in petri dishes containing $25 \mathrm{~mL}$ down different nutrient media at a rate of 10 seeds per box lined with blotting paper to produce seedlings for a period of 4 weeks.

To investigate this we used conventional medium containing sodium chlorine $(\mathrm{NaCl})$ at different concentrations $(1 \mathrm{~g} / \mathrm{L}, 3 \mathrm{~g} / \mathrm{L}$ and $5 \mathrm{~g} / \mathrm{L})$ and two artificial media that are available in our laboratories (nutrient agar, and Potatoes Dextrose Agar) we experienced at temperatures of $4^{\circ} \mathrm{C}, 25^{\circ} \mathrm{C}$ and $30^{\circ} \mathrm{C}$.

\subsection{Study Sites}

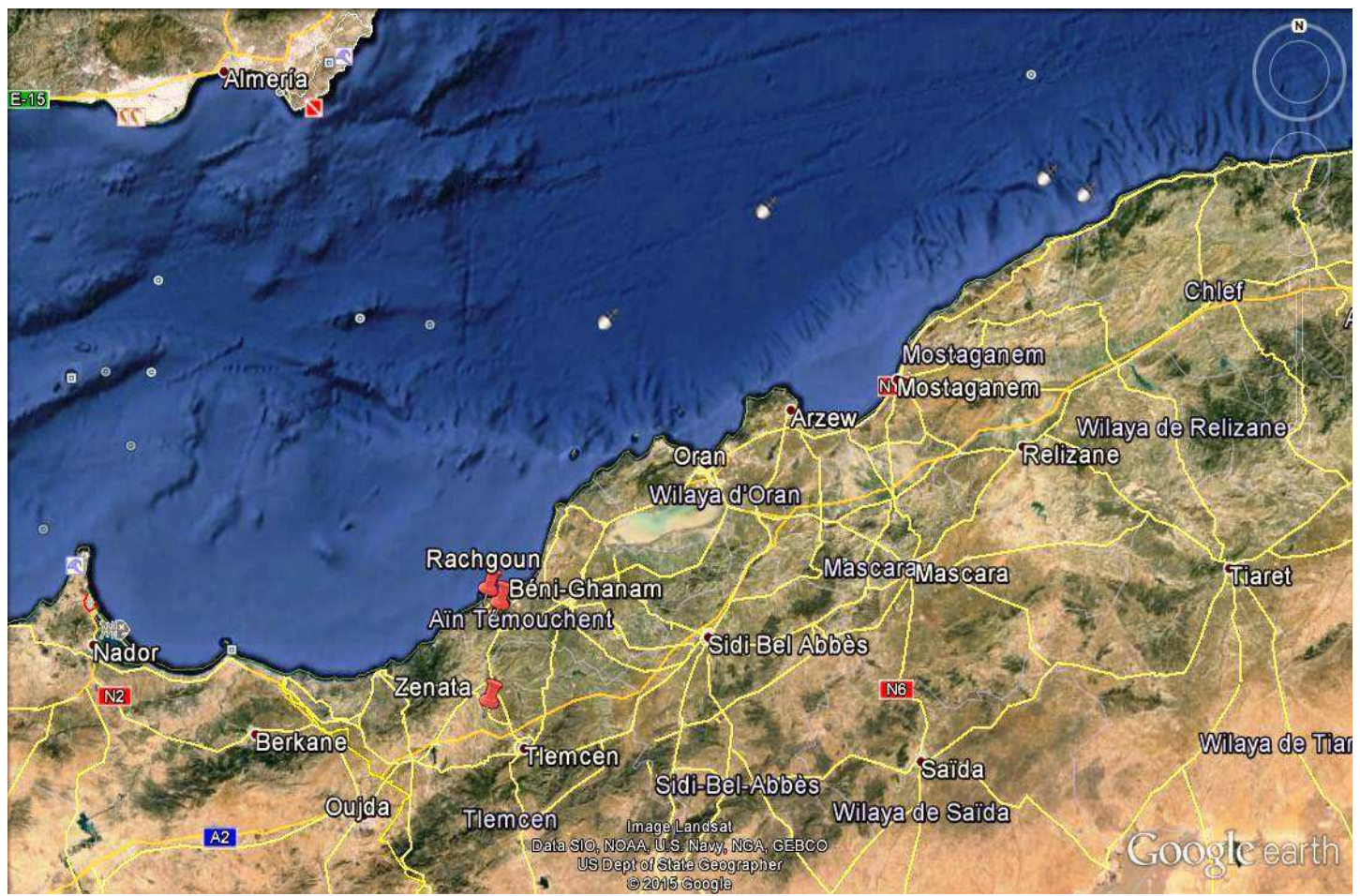

Geographical location map

\subsubsection{Zenata station}

This station is located under the bridge in the national road RN 98 a few kilometers from the town of Zenata. It is located $1^{\circ} 27^{\prime}$ West and $35^{\circ} 01^{\prime}$ north, and the approximate altitude of the station is at $200 \mathrm{~m}$.

\subsubsection{Beni-Ghanam station}

Located $1^{\circ} 17^{\prime}$ West and $35^{\circ} 10^{\prime}$ north and altitudinal level at $180 \mathrm{~m}$,this second station is close to the national road 22 .

\subsubsection{Rachgoun station}

This last station located west of Beni Saf and east of the
Traras Mountains and is located at the mouth of Tafna Wadi near Rachgoun beach.

It is of $1^{\circ} 28^{\prime}$ west and $35^{\circ} 17^{\prime}$ north and its altitude is $54 \mathrm{~m}$.

\section{Results and Interpretations}

In vitro culture technique requires great care in maintaining cultures aseptically.

When we have infected cultures, this may have various causes; it may be a fungus (mold) or a bacterium. If it is a fungus, we can see a mycelial development which has a whitish, greenish or grayish texture. If it is a bacterium, then 
one can see a fog/veil of milky appearance, developed inside the medium and at the surface. If the infection starts from the contact area between the tissue and the medium, then the tissues are the sources of the infection which can be either to air or to an inadequate sterilization of the medium, or a contamination of ambient air through the water condensation of the lid (Augé and al., 1989).

According to Boccon-Gibod (1984) quoted by Heller (1990), it is the explants that are the source of infection. There also may be infections because of improper handling or use of non-sterile equipment. Aseptic conditions are difficult to create/reach in a laboratory (Loukidi, 1998).

The percentage of infection found on hypocotyls appears to be due to incomplete sterilization of seed, probably because of deep fungal infection. There are some simple and reactive techniques that can be used to ensure aseptic working conditions (Herbert and al., 1993; Loukidi, 1998).

The germinated seeds were counted regularly, taking as germination criteria the envelopes breakthrough by the radicle. This allows drawing germination graphs which describe the course of the cumulative germination as function of time.

Table 1. Number of germinated seeds in Nutrient Agar medium, (Room temperature: $25^{\circ} \mathrm{C}$ ).

\begin{tabular}{|c|c|c|c|c|c|c|c|c|}
\hline \multirow{2}{*}{$\begin{array}{l}\text { Weeks } \\
\text { Stations }\end{array}$} & \multicolumn{2}{|l|}{$1^{\text {st }}$ Week } & \multicolumn{2}{|l|}{$2^{\text {nd }}$ Week } & \multicolumn{2}{|l|}{$3^{\text {rd Week }}$} & \multicolumn{2}{|l|}{$4^{\text {th }}$ Week } \\
\hline & Number & $\%$ & Number & $\%$ & Number & $\%$ & Number & $\%$ \\
\hline Zenata & 0 & 0 & 4 & 40 & 5 & 50 & 7 & 70 \\
\hline Beni-Ghanam & 0 & 0 & 2 & 20 & 3 & 30 & 5 & 50 \\
\hline Rachgoun & 1 & 10 & 2 & 20 & 10 & 100 & 10 & 100 \\
\hline
\end{tabular}
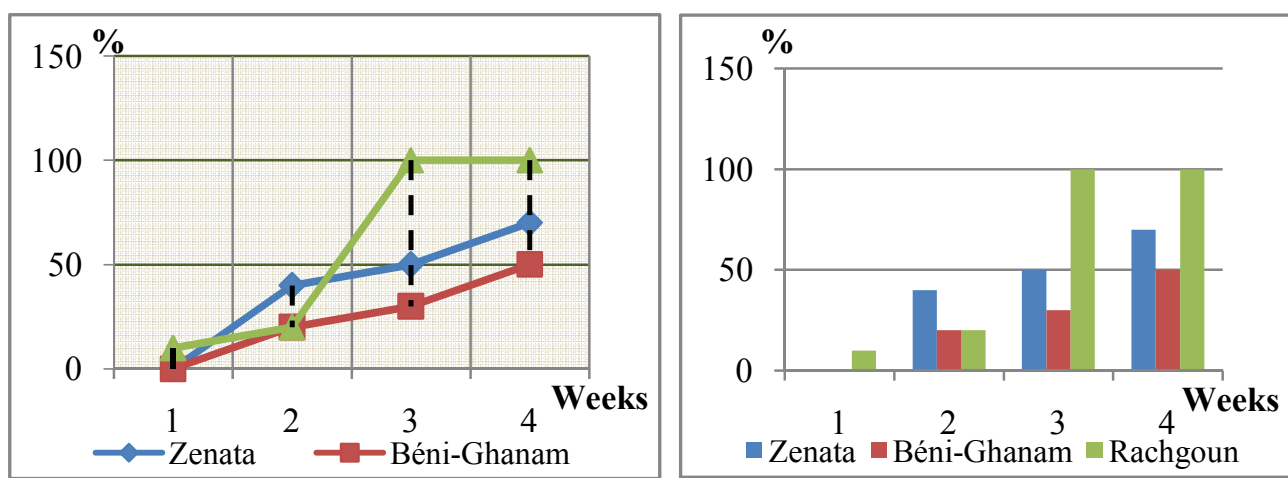

Figures 1. Number of germinated seeds in Nutrient Agar medium, (Room temperature: $25^{\circ} \mathrm{C}$ ).

Germination in room conditions $\left(25^{\circ} \mathrm{C}\right)$ and agar.

- Zenata station: during the first week there was no germination, beginning the second week only germination shows successive increases, and moved sharply to $70 \%$ in the fourth week.

- Beni-Ghanam station: germination snaps from the 2nd week, and then it increases steadily until the fourth week where it reaches $50 \%$.

- Rachgoun station: during the first week no germination was recorded; it was only from the second to the 4th week that germination shows successive increases to reach $100 \%$.

Table 2. Number of germinated seeds in Nutrient Agar medium, with an average temperature at $30^{\circ} \mathrm{C}$.

\begin{tabular}{|c|c|c|c|c|c|c|c|c|}
\hline \multirow{2}{*}{$\begin{array}{l}\text { Weeks } \\
\text { Stations }\end{array}$} & \multicolumn{2}{|l|}{$1^{\text {st }}$ Week } & \multicolumn{2}{|l|}{$2^{\text {nd }}$ Week } & \multicolumn{2}{|l|}{$3^{\text {rd Week }}$} & \multicolumn{2}{|l|}{$4^{\text {th }}$ Week } \\
\hline & Number & $\%$ & Number & $\%$ & Number & $\%$ & Number & $\%$ \\
\hline Zenata & 6 & 60 & 6 & 60 & 6 & 60 & 6 & 60 \\
\hline Béni-Ghanam & 0 & 0 & 0 & 0 & 0 & 0 & 0 & 0 \\
\hline Rachgoun & 0 & 0 & 0 & 0 & 0 & 0 & 0 & 0 \\
\hline
\end{tabular}
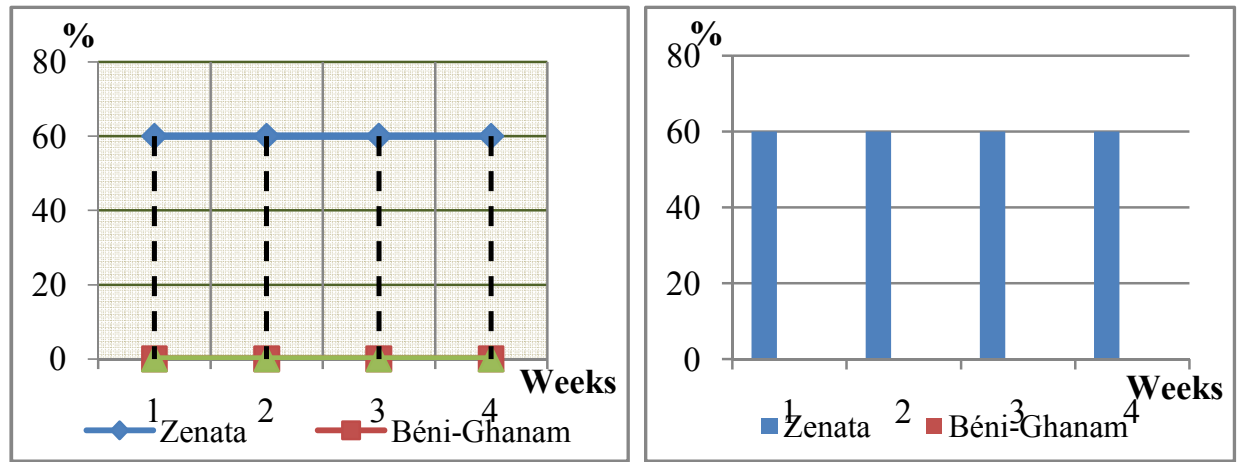

Figures2. Number of germinated seeds in Nutrient Agar medium, with an average temperature at $30^{\circ} \mathrm{C}$. 
Germination at average temperature $\left(30^{\circ} \mathrm{C}\right)$ and agar.

This germination case is very surprising; only the seeds of
Zenata station responded favorably with $60 \%$ (steady from the beginning to the end of the experiment).

Table 3. Number of germinated seeds in Nutrient Agar medium. (Cold Temperature: $4^{\circ} \mathrm{C}$ ).

\begin{tabular}{|c|c|c|c|c|c|c|c|c|}
\hline \multirow{2}{*}{$\begin{array}{l}\text { Weeks } \\
\text { Stations }\end{array}$} & \multicolumn{2}{|l|}{$1^{\text {st }}$ Week } & \multicolumn{2}{|l|}{$2^{\text {nd }}$ Week } & \multicolumn{2}{|l|}{$3^{\text {rd Week }}$} & \multicolumn{2}{|l|}{$4^{\text {th }}$ Week } \\
\hline & Number & $\%$ & Number & $\%$ & Number & $\%$ & Number & $\%$ \\
\hline Zenata & 0 & 0 & 0 & 0 & 0 & 0 & 0 & 0 \\
\hline Béni-Ghanam & 0 & 0 & 0 & 0 & 1 & 10 & 1 & 10 \\
\hline Rachgoun & 3 & 30 & 5 & 50 & 5 & 50 & 6 & 60 \\
\hline
\end{tabular}
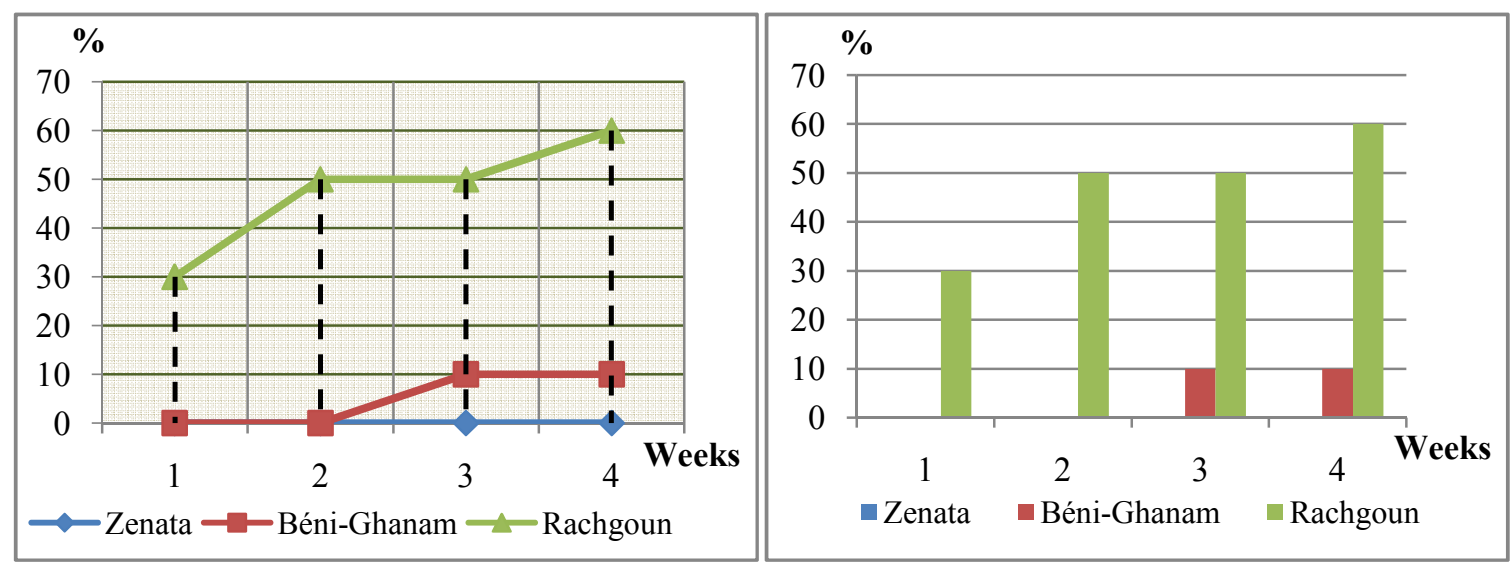

Figures 3. Number of germinated seeds in Nutrient Agar medium. (Cold Temperature: $4^{\circ} \mathrm{C}$ ).

Germination in cold temperature $\left(4^{\circ} \mathrm{C}\right)$ and agar

Like the latter study case, this germination is also very surprising as only Zenata station seeds responded favorably with $60 \%$ (steady from the beginning to the end of the experiment).

Table 4. Number of germinated seeds in the PDA medium. (at room temperature, $25^{\circ} \mathrm{C}$ ).

\begin{tabular}{|c|c|c|c|c|c|c|c|c|}
\hline \multirow{2}{*}{$\begin{array}{l}\text { Weeks } \\
\text { Stations }\end{array}$} & \multicolumn{2}{|l|}{$1^{\text {st }}$ Week } & \multicolumn{2}{|l|}{$2^{\text {nd }}$ Week } & \multicolumn{2}{|l|}{$3^{\text {rd Week }}$} & \multicolumn{2}{|l|}{$4^{\text {th }}$ Week } \\
\hline & Number & $\%$ & Number & $\%$ & Number & $\%$ & Number & $\%$ \\
\hline Zenata & 7 & 70 & 7 & 70 & 10 & 100 & 10 & 100 \\
\hline Béni-Ghanam & 3 & 30 & 4 & 40 & 4 & 40 & 4 & 40 \\
\hline Rachgoun & 5 & 50 & 6 & 60 & 8 & 80 & 8 & 80 \\
\hline
\end{tabular}
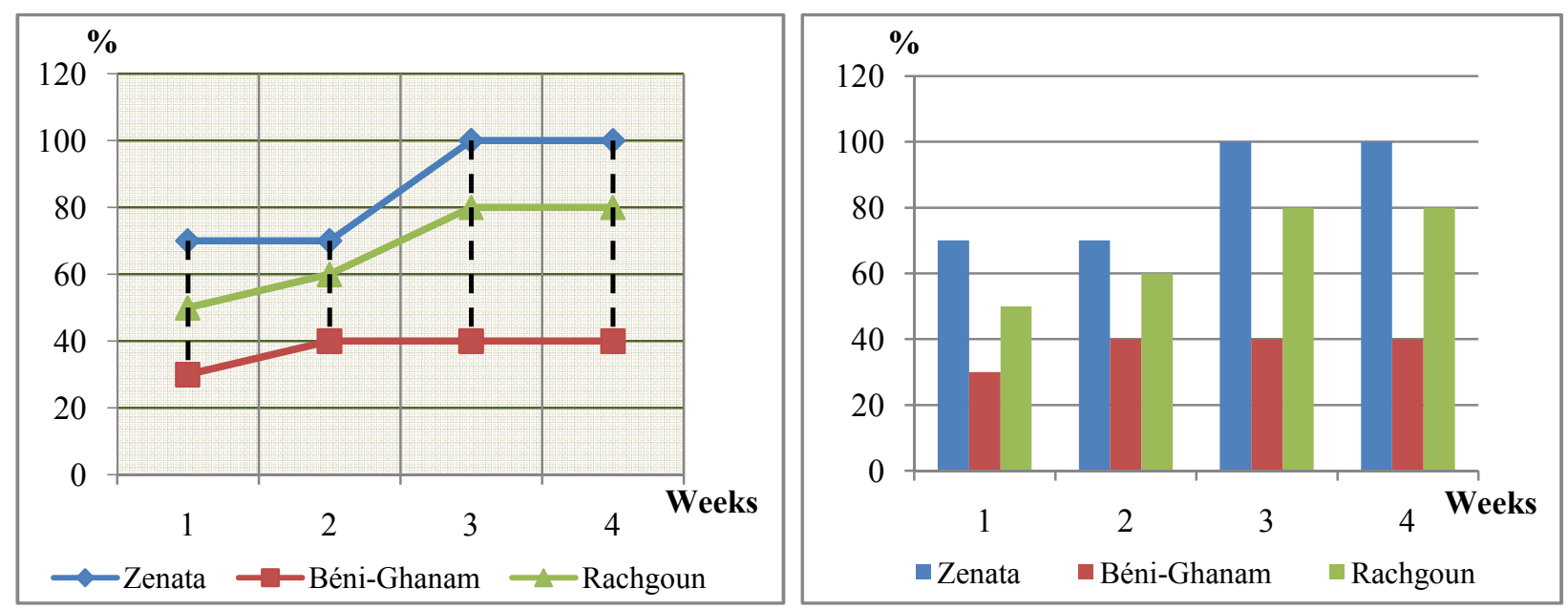

Figures 4. Number of germinated seeds in the PDA medium. (at room temperature, $25^{\circ} \mathrm{C}$ ).

Germination in room conditions $\left(25^{\circ} \mathrm{C}\right)$ and PDA medium

- Zenata station: during the first and the second week we had $70 \%$ of germination, this rate reaches $100 \%$ in the last two weeks.

- Beni-Ghanam station: during the first week we have $30 \%$ of germination; from the $2^{\text {nd }}$ to the $4^{\text {th }}$ week it stabilizes at $40 \%$.

- Rachgoun station: during the first week, germination starts at $50 \%$, it is only in the second and 4th week that germination shows successive increases, we went from 
$60 \%$ to $80 \%$.

Table 5. Number of germinated seeds in the PDA environment. (Average temperature $30^{\circ} \mathrm{C}$ ).

\begin{tabular}{|c|c|c|c|c|c|c|c|c|}
\hline \multirow{2}{*}{$\begin{array}{l}\text { Weeks } \\
\text { Stations }\end{array}$} & \multicolumn{2}{|l|}{$1^{\text {st }}$ Week } & \multicolumn{2}{|l|}{$2^{\text {nd }}$ Week } & \multicolumn{2}{|l|}{$3^{\text {rd Week }}$} & \multicolumn{2}{|l|}{$4^{\text {th Week }}$} \\
\hline & Number & $\%$ & Number & $\%$ & Number & $\%$ & Number & $\%$ \\
\hline Zenata & 5 & 50 & 5 & 50 & 6 & 60 & 6 & 60 \\
\hline Béni-Ghanam & 10 & 100 & 10 & 100 & 10 & 100 & 10 & 100 \\
\hline Rachgoun & 4 & 40 & 4 & 40 & 5 & 50 & 5 & 50 \\
\hline
\end{tabular}
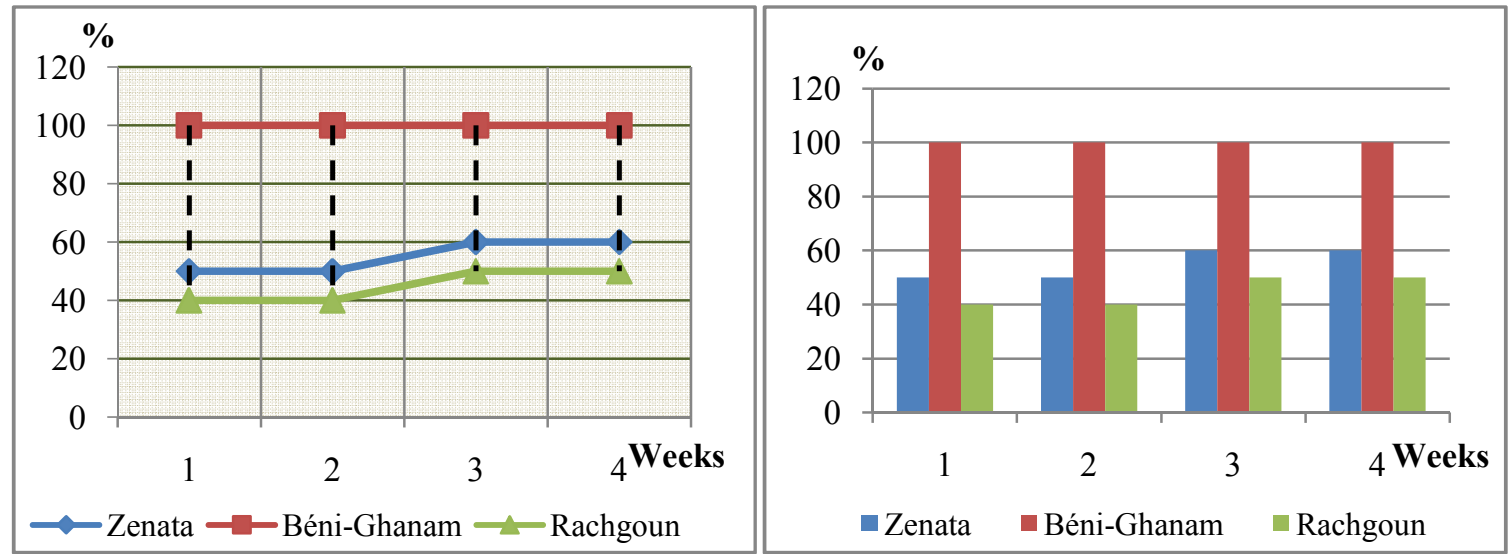

Figures 5. Number of germinated seeds in the PDA environment. (Averagetemperature $30^{\circ} \mathrm{C}$ ).

Germination took place in an average temperature $\left(30^{\circ} \mathrm{C}\right)$ and PDA medium.

- Zenata station: during the first week, germination rate is $50 \%$, this percentage has stabilized at the 2 nd week. During the third and fourth week we see significant increases $(50 \%$ to $60 \%)$.
- Beni-Ghanam station: during the 4 weeks, we record a maximum germination which already appears at the first week (100\%).

- Rachgoun station: after a sudden direct $40 \%$ rise, germination is stable up to week 4 and shows a $50 \%$ small increase.

Table 6. Number of germinated seeds in the PDA environment. (Cold temperature: $4^{\circ} \mathrm{C}$ )

\begin{tabular}{|c|c|c|c|c|c|c|c|c|}
\hline \multirow{2}{*}{$\begin{array}{l}\text { Weeks } \\
\text { Stations }\end{array}$} & \multicolumn{2}{|l|}{$1^{\text {st Week }}$} & \multicolumn{2}{|l|}{$2^{\text {nd }}$ Week } & \multicolumn{2}{|l|}{$3^{\text {rd Week }}$} & \multicolumn{2}{|l|}{$4^{\text {th }}$ Week } \\
\hline & Number & $\%$ & Number & $\%$ & Number & $\%$ & Number & $\%$ \\
\hline Zenata & 0 & 0 & 0 & 0 & 0 & 0 & 2 & 20 \\
\hline Béni-Ghanam & 0 & 0 & 0 & 0 & 0 & 0 & 1 & 10 \\
\hline Rachgoun & 0 & 0 & 1 & 10 & 1 & 10 & 2 & 20 \\
\hline
\end{tabular}
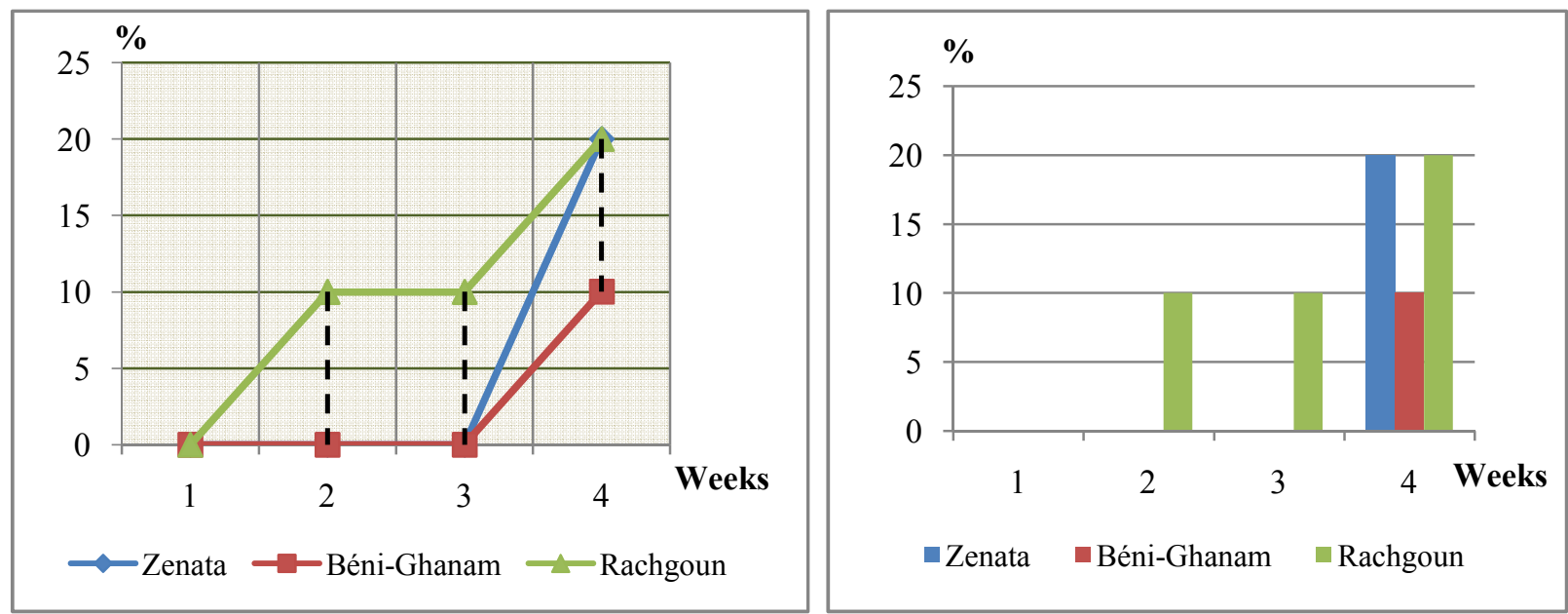

Figures 6. Number of germinated seeds in the PDA environment. (Cold temperature: $4^{\circ} \mathrm{C}$ )

This germination is conducted at cold temperature $\left(4^{\circ} \mathrm{C}\right)$ in PDA medium.

- Zenata station: germination occurs at the fourth week with a relatively small percentage $(20 \%)$.
- Beni-Ghanam station: germination takes place only at the fourth week with a very small percentage $(10 \%)$.

- Rachgoun station: germination begins in the 2 ndweek $(10 \%)$, stabilizes during the third, ending ultimately the 
4thweek with a percentage of $20 \%$.

Table 7. Number of germinated seeds in a medium with salt concentration $(1 \mathrm{~g} / \mathrm{L} \mathrm{of} \mathrm{NaCl})$ at room temperature $\left(25^{\circ} \mathrm{C}\right)$.

\begin{tabular}{|c|c|c|c|c|c|c|c|c|}
\hline \multirow{2}{*}{$\begin{array}{l}\text { Weeks } \\
\text { Stations }\end{array}$} & \multicolumn{2}{|l|}{$1^{\text {st Week }}$} & \multicolumn{2}{|l|}{$2^{\text {nd }}$ Week } & \multicolumn{2}{|l|}{$3^{\text {rd Week }}$} & \multicolumn{2}{|l|}{$4^{\text {th }}$ Week } \\
\hline & Number & $\%$ & Number & $\%$ & Number & $\%$ & Number & $\%$ \\
\hline Zenata & 0 & 0 & 10 & 100 & 10 & 100 & 10 & 100 \\
\hline Béni-Ghanam & 0 & 0 & 0 & 0 & 0 & 0 & 0 & 0 \\
\hline Rachgoun & 0 & 0 & 10 & 100 & 10 & 100 & 10 & 100 \\
\hline
\end{tabular}
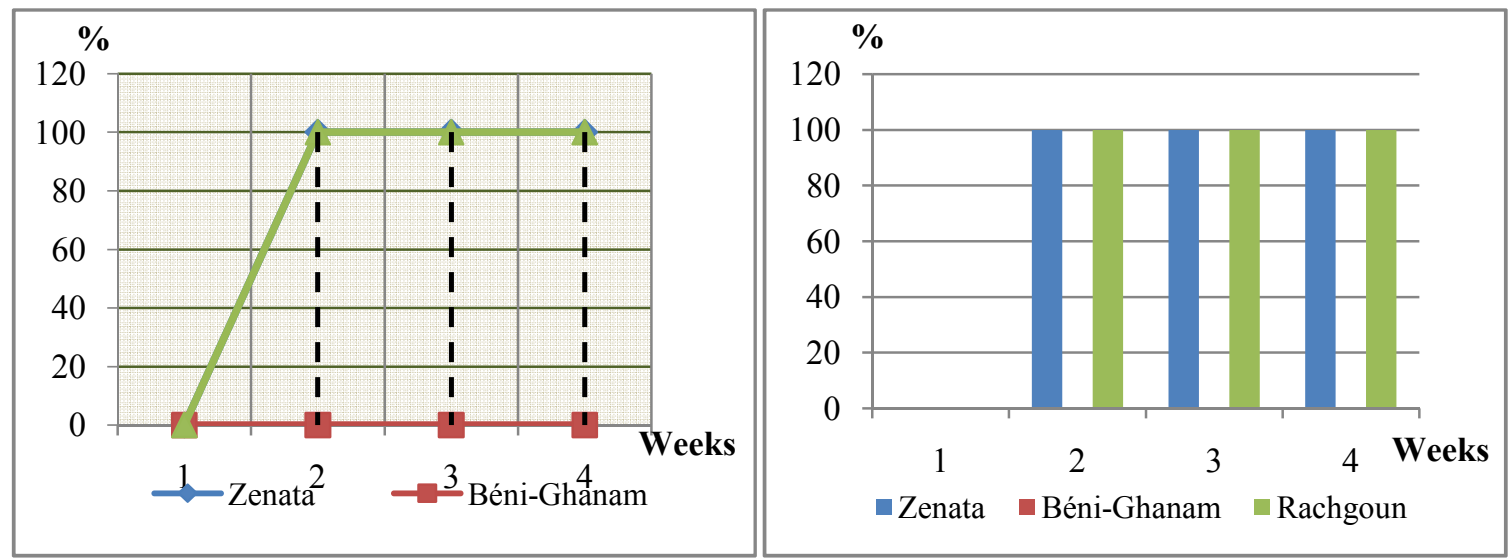

Figures 7. Number of germinated seeds in a medium with salt concentration $(1 \mathrm{~g} / \mathrm{L}$ of $\mathrm{NaCl})$ at room temperature $\left(25^{\circ} \mathrm{C}\right)$.

Seed germination in a medium with a salt concentration $(\mathrm{NaCl}) 1 \mathrm{~g} / \mathrm{L}$ in room conditions $\left(25^{\circ} \mathrm{C}\right)$ evolves in stations as follows:

- Zenata station: germination starts from the second week by showing a maximum $(100 \%)$.
- Beni-Ghanam station: no sprouting here from the beginning to the end of the experiment.

- Rachgoun station: germination followed the same pattern as that of the Zenata station.

Table 8. Number of germinated seeds in a medium with salt concentration $(1 \mathrm{~g} / \mathrm{L} \mathrm{of} \mathrm{NaCl})$ at medium temperature $\left(30^{\circ} \mathrm{C}\right)$.

\begin{tabular}{|c|c|c|c|c|c|c|c|c|}
\hline \multirow{2}{*}{$\begin{array}{l}\text { Weeks } \\
\text { Stations }\end{array}$} & \multicolumn{2}{|l|}{$1^{\text {st Week }}$} & \multicolumn{2}{|l|}{$2^{\text {nd }}$ Week } & \multicolumn{2}{|l|}{$3^{\text {rd Week }}$} & \multicolumn{2}{|l|}{$4^{\text {th }}$ Week } \\
\hline & Number & $\%$ & Number & $\%$ & Number & $\%$ & Number & $\%$ \\
\hline Zenata & 0 & 0 & 0 & 0 & 0 & 0 & 0 & 0 \\
\hline Béni-Ghanam & 0 & 0 & 0 & 0 & 0 & 0 & 2 & 20 \\
\hline Rachgoun & 0 & 0 & 1 & 10 & 1 & 10 & 2 & 20 \\
\hline
\end{tabular}
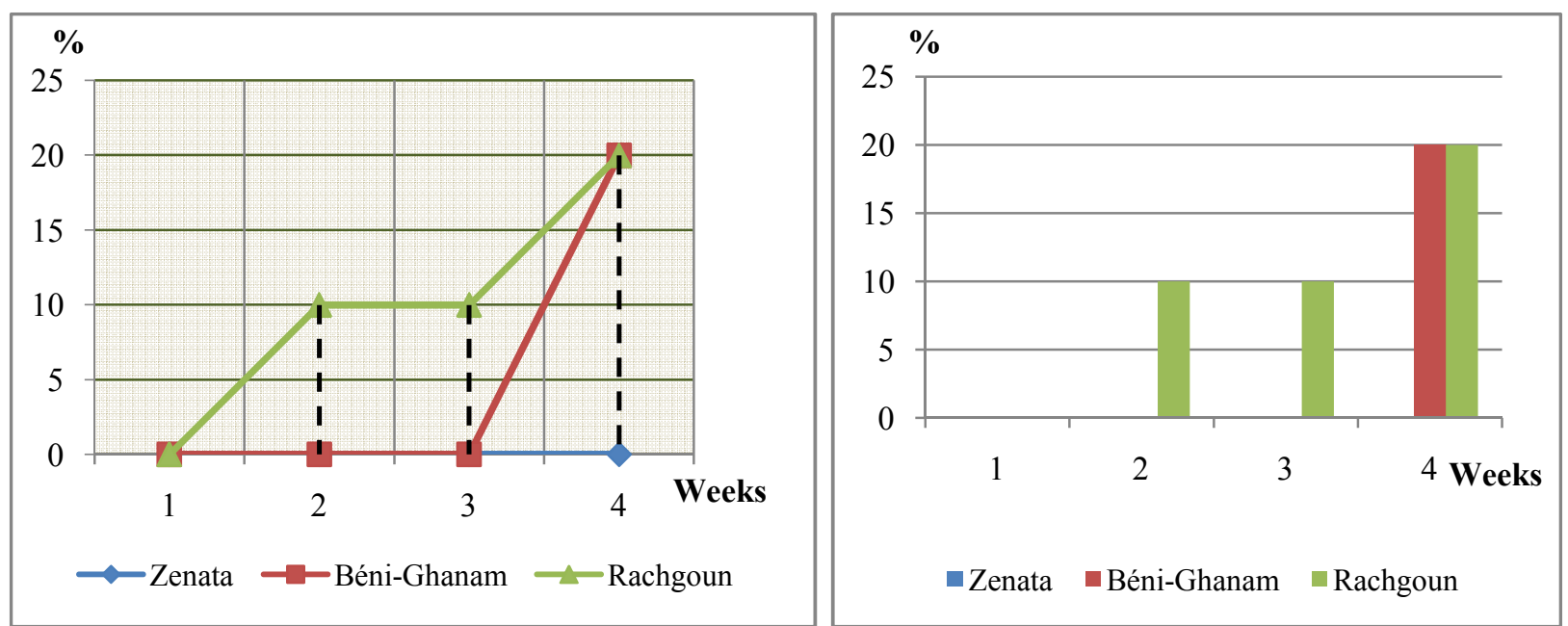

Figures 8. Number of germinated seeds in a medium with salt concentration $\left(1 \mathrm{~g} / \mathrm{L}\right.$ of $\mathrm{NaCl}$ ) at medium temperature $\left(30^{\circ} \mathrm{C}\right)$.

Seed germination in a medium with a $1 \mathrm{~g} / \mathrm{L}$ of $\mathrm{NaCl}$ concentration and at an average temperature of $30^{\circ} \mathrm{C}$ :

- Zenata station: no sprouting is obtained in the four weeks of experimentation.
- Beni-Ghanam station: we record germination only in the fourth week, and that remains however low (20\%).

- Rachgoun station: germination begins in the second week, remains steady in the third to finish at a rate of $20 \%$ 
the last week.

Table 9. Number of germinated seeds in a medium with $1 \mathrm{~g} / \mathrm{L}$ salt concentration $(\mathrm{NaCl})$ in cold temperature $\left(4^{\circ} \mathrm{C}\right)$.

\begin{tabular}{|c|c|c|c|c|c|c|c|c|}
\hline \multirow{2}{*}{$\begin{array}{l}\text { Weeks } \\
\text { Stations }\end{array}$} & \multicolumn{2}{|l|}{$1^{\text {st }}$ Week } & \multicolumn{2}{|l|}{$2^{\text {nd }}$ Week } & \multicolumn{2}{|l|}{$3^{\text {rd Week }}$} & \multicolumn{2}{|l|}{$4^{\text {th }}$ Week } \\
\hline & Number & $\%$ & Number & $\%$ & Number & $\%$ & Number & $\%$ \\
\hline Zenata & 0 & 0 & 0 & 0 & 1 & 10 & 2 & 20 \\
\hline Béni-Ghanam & 0 & 0 & 0 & 0 & 0 & 0 & 3 & 30 \\
\hline Rachgoun & 0 & 0 & 6 & 60 & 7 & 70 & 8 & 80 \\
\hline
\end{tabular}
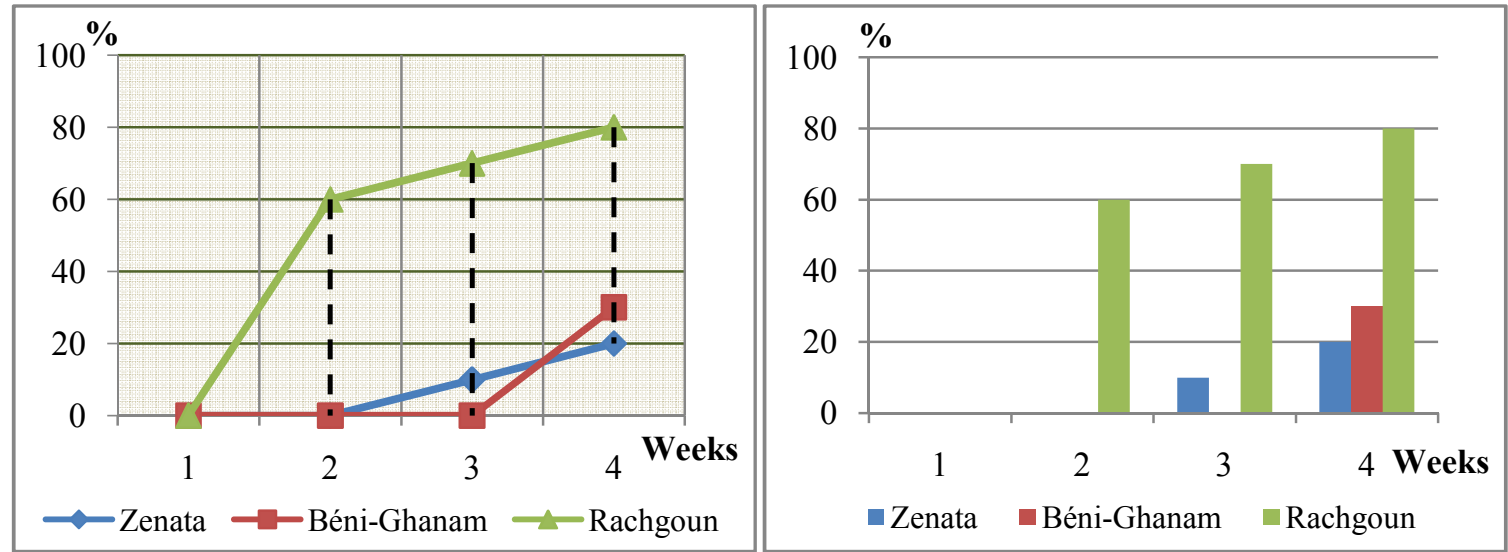

Figures 9. Number of germinated seeds in a medium with $1 \mathrm{~g} / \mathrm{L}$ salt concentration $(\mathrm{NaCl})$ in cold temperature $\left(4^{\circ} \mathrm{C}\right)$.

Seed germination in a medium with $1 \mathrm{~g} / \mathrm{L}(\mathrm{NaCl}$ concentration) in cold temperature $\left(4^{\circ} \mathrm{C}\right)$ showing the following changes:

- Zenat astation: germination starts the third week with $10 \%$, and then shows a change in the fourth week with $20 \%$.
- Beni-Ghanam station: germination is recorded until the fourth week with a comparatively low (30\%).

- Rachgoun station: germination snaps during the second week $(60 \%)$, and increases in the last two with 70 and $80 \%$ respectively.

Table 10. Number of germinated seeds in a medium with $3 \mathrm{~g} / \mathrm{L}$ salt concentration (NaCl) at room temperature $\left(25^{\circ} \mathrm{C}\right)$.

\begin{tabular}{|c|c|c|c|c|c|c|c|c|}
\hline \multirow{2}{*}{$\begin{array}{l}\text { Weeks } \\
\text { Stations }\end{array}$} & \multicolumn{2}{|l|}{$1^{\text {st }}$ Week } & \multicolumn{2}{|l|}{$2^{\text {nd }}$ Week } & \multicolumn{2}{|l|}{$3^{\text {rd Week }}$} & \multicolumn{2}{|l|}{$4^{\text {th }}$ Week } \\
\hline & Number & $\%$ & Number & $\%$ & Number & $\%$ & Number & $\%$ \\
\hline Zenata & 0 & 0 & 0 & 0 & 0 & 0 & 0 & 0 \\
\hline Béni-Ghanam & 0 & 0 & 0 & 0 & 0 & 0 & 0 & 0 \\
\hline Rachgoun & 0 & 0 & 10 & 100 & 10 & 100 & 10 & 100 \\
\hline
\end{tabular}
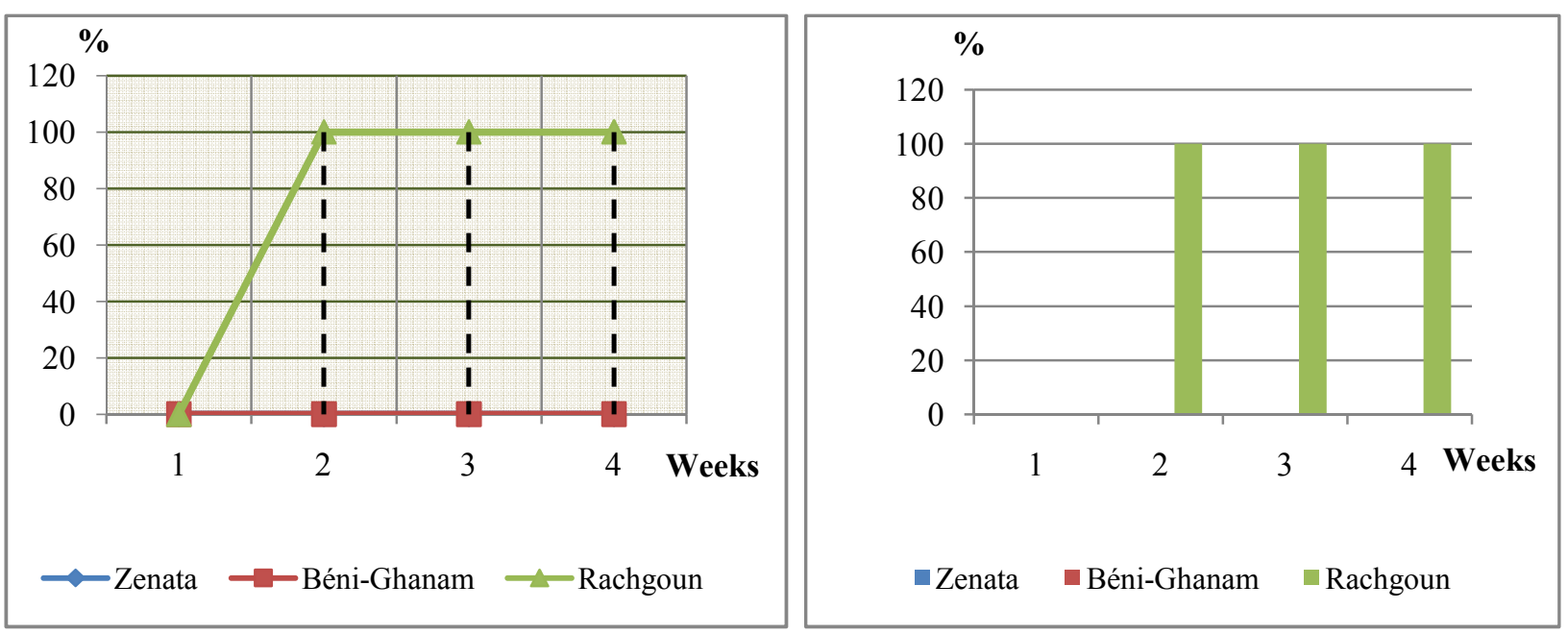

Figures 10. Number of germinated seeds in a medium with $3 \mathrm{~g} / \mathrm{L}$ salt concentration (NaCl) at room temperature $\left(25^{\circ} \mathrm{C}\right)$.

Seed germination in a medium with a $3 \mathrm{~g} / \mathrm{L}$ salt concentration $(\mathrm{NaCl})$ in room conditions $\left(25^{\circ} \mathrm{C}\right)$ allows to note:
Only Rachgoun station shows a maximum germination from the second week (100\%), and of course remains steady during the other weeks. 
The other two stations (Beni-Ghanam and Zenata showed

no germination.

Table 11. Number of germinated seeds in a medium with $3 g / L$ salt concentration $\left(\mathrm{NaCl}\right.$ ) at $30^{\circ} \mathrm{Ctemperature.}$

\begin{tabular}{lllllllll}
\hline Weeks & $\mathbf{1}^{\text {st }}$ Week & & $\mathbf{2}^{\text {nd }}$ Week & & $\mathbf{3}^{\text {rd }}$ Week & & $\mathbf{4}^{\text {th }}$ Week \\
Stations & Number & $\mathbf{\%}$ & Number & $\mathbf{\%}$ & Number & $\mathbf{\%}$ & Number & $\mathbf{\%}$ \\
\hline Zenata & 0 & 0 & 2 & 20 & 2 & 20 & 2 \\
Béni-Ghanam & 0 & 0 & 0 & 0 & 0 & 0 & 0 \\
Rachgoun & 0 & 0 & 0 & 0 & 1 & 10 & 4 \\
\hline
\end{tabular}
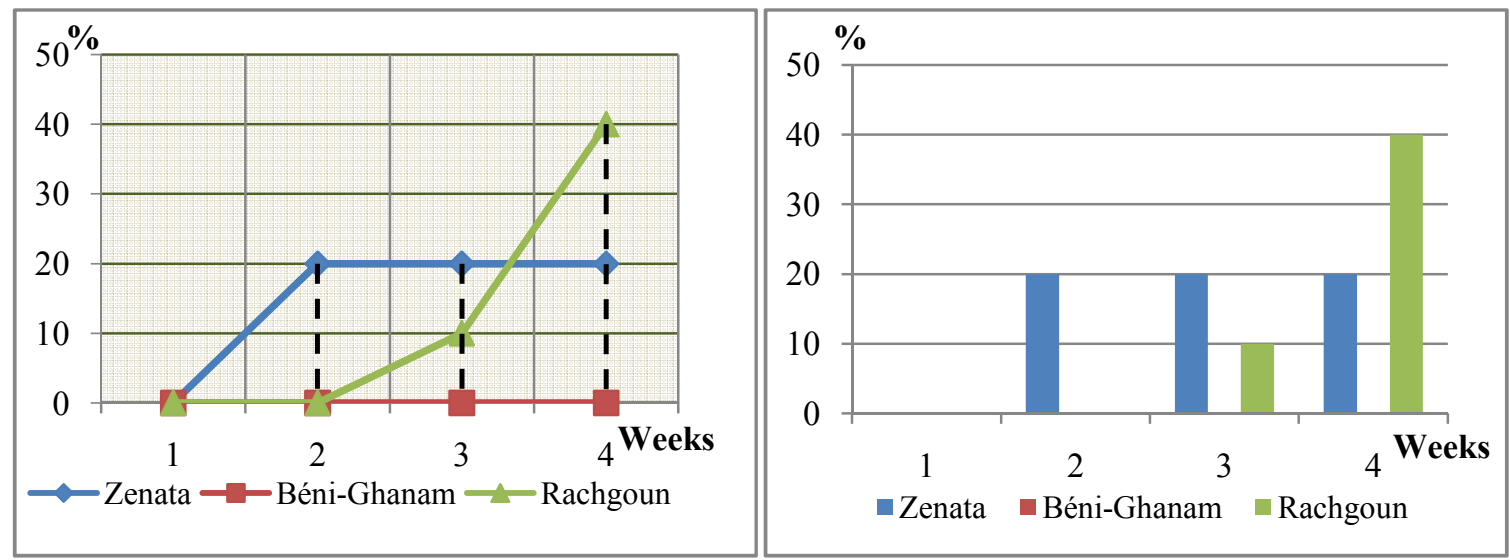

Figures 11. Number of germinated seeds in a medium with $3 \mathrm{~g} / \mathrm{L}$ salt concentration ( $\mathrm{NaCl}$ ) at $30^{\circ} \mathrm{Ctemperature.}$

Seed germination in a medium with salt concentration $(\mathrm{NaCl}) 3 \mathrm{~g} / \mathrm{L}$ room conditions $\left(30^{\circ} \mathrm{C}\right)$ allows the following remarks:

- Zenata station: germination snaps the 2ndweek with $20 \%$ and this rate remains steady during the other weeks.
- Beni-Ghanam station: no germination seen at this station.

- Rachgoun station: germination takes place only from the third week (10\%) and ends with $40 \%$ in the 4 th week.

Table 12. Number of germinated seeds in a medium with $3 \mathrm{~g} / \mathrm{L}$ salt concentration $(\mathrm{NaCl})$ at cold temperature $\left(4^{\circ} \mathrm{C}\right)$.

\begin{tabular}{|c|c|c|c|c|c|c|c|c|}
\hline \multirow{2}{*}{$\begin{array}{l}\text { Weeks } \\
\text { Stations }\end{array}$} & \multicolumn{2}{|l|}{$1^{\text {st }}$ Week } & \multicolumn{2}{|l|}{$2^{\text {nd }}$ Week } & \multicolumn{2}{|l|}{$3^{\text {rd Week }}$} & \multicolumn{2}{|l|}{$4^{\text {th Week }}$} \\
\hline & Number & $\%$ & Number & $\%$ & Number & $\%$ & Number & $\%$ \\
\hline Zenata & 0 & 0 & 2 & 20 & 7 & 70 & 10 & 100 \\
\hline Béni-Ghanam & 0 & 0 & 3 & 30 & 5 & 50 & 5 & 50 \\
\hline Rachgoun & 0 & 0 & 1 & 10 & 4 & 40 & 5 & 50 \\
\hline
\end{tabular}
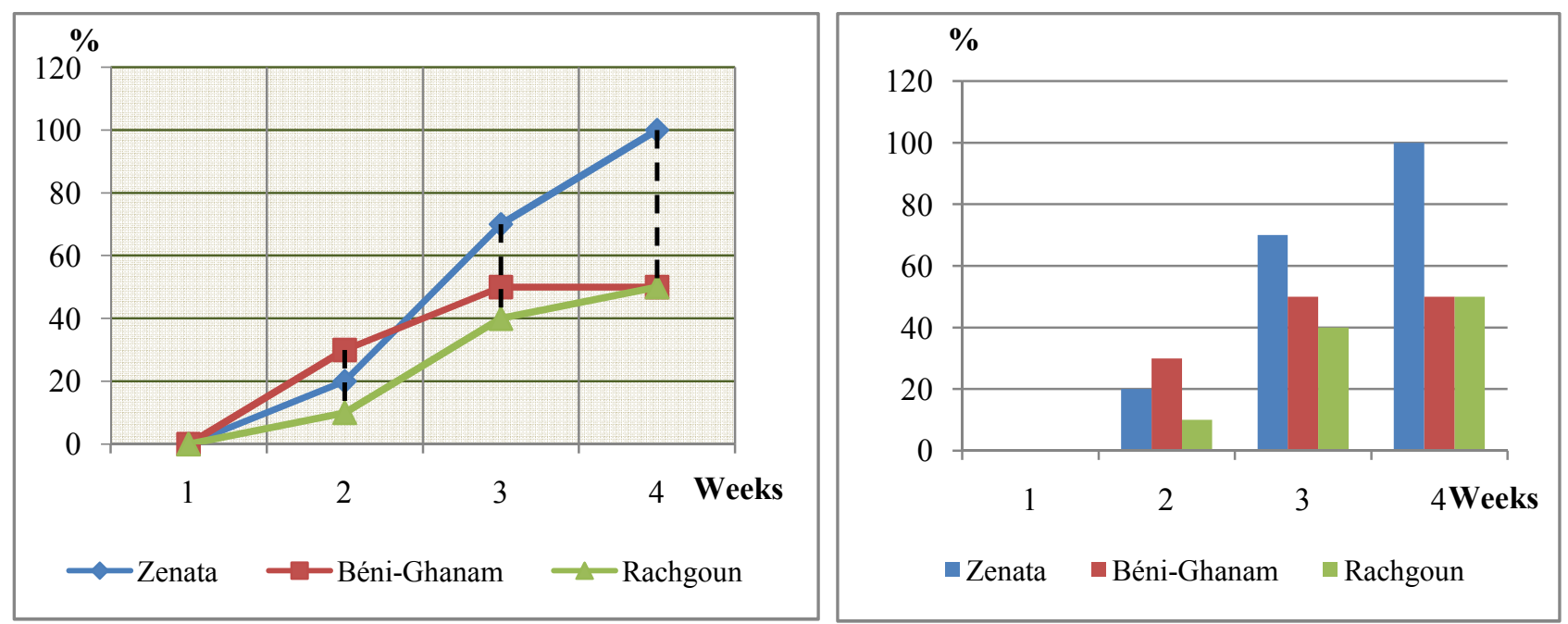

Figures12. Number of germinated seeds in a medium with $3 \mathrm{~g} / \mathrm{L}$ salt concentration $(\mathrm{NaCl})$ at cold temperature $\left(4^{\circ} \mathrm{C}\right)$.

Seed germination in a medium with $3 \mathrm{~g} / \mathrm{L}$ salt concentration $(\mathrm{NaCl})$ in cold temperature $\left(4^{\circ} \mathrm{C}\right)$ allows to note:

- Zenata station: germination starts the second week with
$20 \%$, rises to $70 \%$ in the third to finish with a maximum $(100 \%)$ in the last week.

- Both stations (Beni-Ghanam and Rachgoun): germination begins the second week with respective 
percentages of 10 and $30 \%$ and ends with an average of

$50 \%$.

Table 13. Number of germinated seeds in a medium with $5 \mathrm{~g} / \mathrm{L}$ salt concentration $(\mathrm{NaCl})$ at room temperature $\left(25^{\circ} \mathrm{C}\right)$.

\begin{tabular}{|c|c|c|c|c|c|c|c|c|}
\hline \multirow{2}{*}{$\begin{array}{l}\text { Weeks } \\
\text { Stations }\end{array}$} & \multicolumn{2}{|l|}{$1^{\text {st }}$ Week } & \multicolumn{2}{|l|}{$2^{\text {nd }}$ Week } & \multicolumn{2}{|l|}{$3^{\text {rd Week }}$} & \multicolumn{2}{|l|}{$4^{\text {th Week }}$} \\
\hline & Number & $\%$ & Number & $\%$ & Number & $\%$ & Number & $\%$ \\
\hline Zenata & 0 & 0 & 0 & 0 & 0 & 0 & 0 & 0 \\
\hline Béni-Ghanam & 0 & 0 & 0 & 0 & 0 & 0 & 0 & 0 \\
\hline Rachgoun & 0 & 0 & 0 & 0 & 0 & 0 & 0 & 0 \\
\hline
\end{tabular}
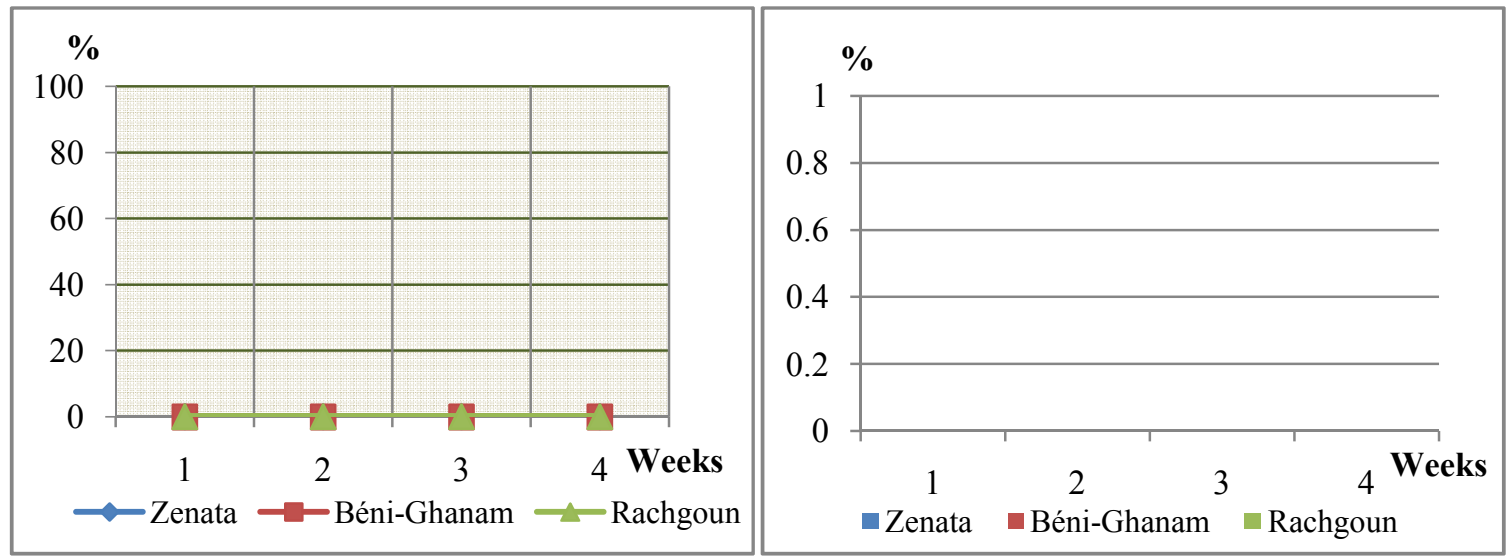

Figures13. Number of germinated seeds in a medium with $5 \mathrm{~g} / \mathrm{L}$ salt concentration $(\mathrm{NaCl})$ at room temperature $\left(25^{\circ} \mathrm{C}\right)$.

Unfortunately, seed germination in a $5 \mathrm{~g} / \mathrm{L}$ salt does not show any germination in the three stations. concentration $(\mathrm{NaCl})$ medium at room conditions $\left(25^{\circ} \mathrm{C}\right)$ :

Table 14. Number of germinated seeds in a $5 \mathrm{~g} / \mathrm{L}$ salt concentration $(\mathrm{NaCl})$ medium at average temperature $\left(30^{\circ} \mathrm{C}\right)$.

\begin{tabular}{|c|c|c|c|c|c|c|c|c|}
\hline \multirow{2}{*}{$\begin{array}{l}\text { Weeks } \\
\text { Stations }\end{array}$} & \multicolumn{2}{|l|}{$1^{\text {st }}$ Week } & \multicolumn{2}{|l|}{$2^{\text {nd }}$ Week } & \multicolumn{2}{|l|}{$3^{\text {rd Week }}$} & \multicolumn{2}{|l|}{$4^{\text {th }}$ Week } \\
\hline & Number & $\%$ & Number & $\%$ & Number & $\%$ & Number & $\%$ \\
\hline Zenata & 0 & 0 & 0 & 0 & 0 & 0 & 3 & 30 \\
\hline Béni-Ghanam & 0 & 0 & 0 & 0 & 0 & 0 & 0 & 0 \\
\hline Rachgoun & 0 & 0 & 0 & 0 & 0 & 0 & 4 & 40 \\
\hline
\end{tabular}
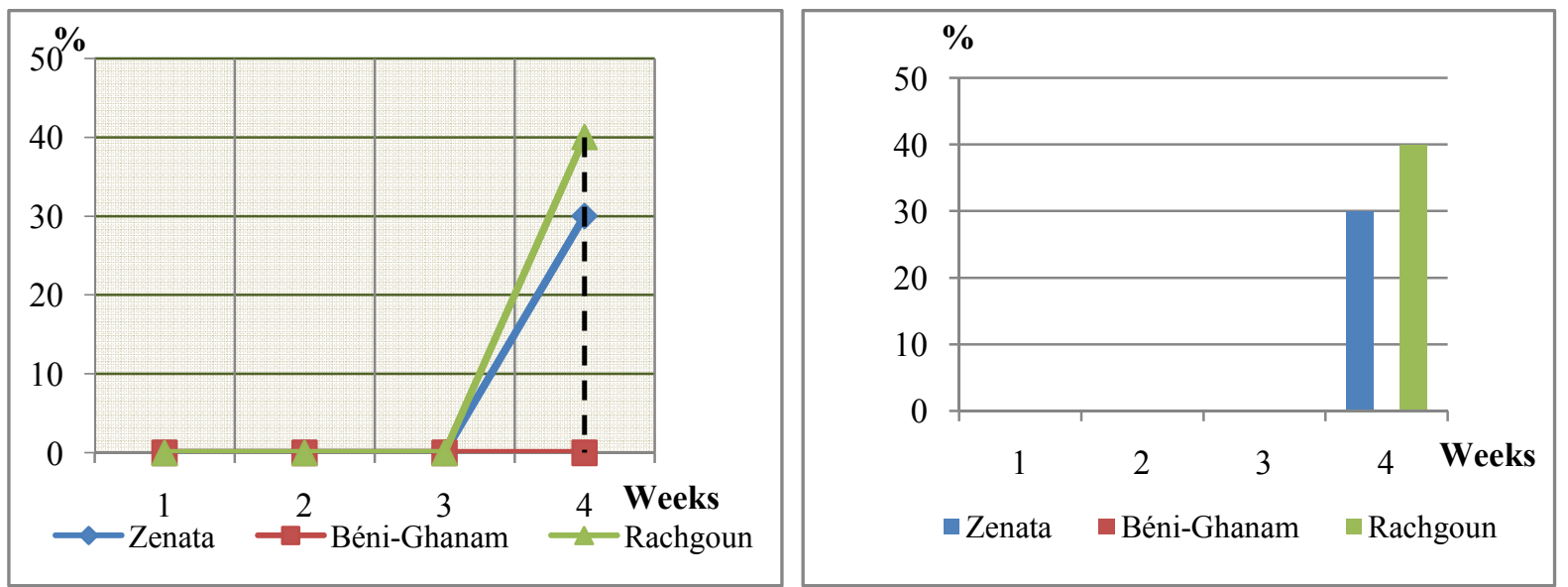

Figures 14. Number of germinated seeds in a $5 \mathrm{~g} / \mathrm{L}$ salt concentration ( $\mathrm{NaCl}$ ) medium at average temperature $\left(30^{\circ} \mathrm{C}\right)$.

Seed germination in a $5 \mathrm{~g} / \mathrm{L}$ salt concentration $(\mathrm{NaCl})$ medium at average temperature $\left(30^{\circ} \mathrm{C}\right)$ shows that germination takes place at the end of the experiment with $30 \%$ in Zenata station and 40\% in Rachgoun station).

Table 15. Number of germinated seeds in a medium with a $5 \mathrm{~g} / \mathrm{L}$ salt concentration ( $\mathrm{NaCl}$ ) at cold temperature $\left(4^{\circ} \mathrm{C}\right)$.

\begin{tabular}{|c|c|c|c|c|c|c|c|c|}
\hline \multirow{2}{*}{$\begin{array}{l}\text { Weeks } \\
\text { Stations }\end{array}$} & \multicolumn{2}{|l|}{$1^{\text {st }}$ Week } & \multicolumn{2}{|l|}{$2^{\text {nd }}$ Week } & \multicolumn{2}{|l|}{$3^{\text {rd Week }}$} & \multicolumn{2}{|l|}{$4^{\text {th }}$ Week } \\
\hline & Number & $\%$ & Number & $\%$ & Number & $\%$ & Number & $\%$ \\
\hline Zenata & 2 & 20 & 8 & 80 & 8 & 80 & 8 & 80 \\
\hline Béni-Ghanam & 2 & 20 & 3 & 30 & 3 & 30 & 3 & 30 \\
\hline Rachgoun & 10 & 100 & 10 & 100 & 10 & 100 & 10 & 100 \\
\hline
\end{tabular}



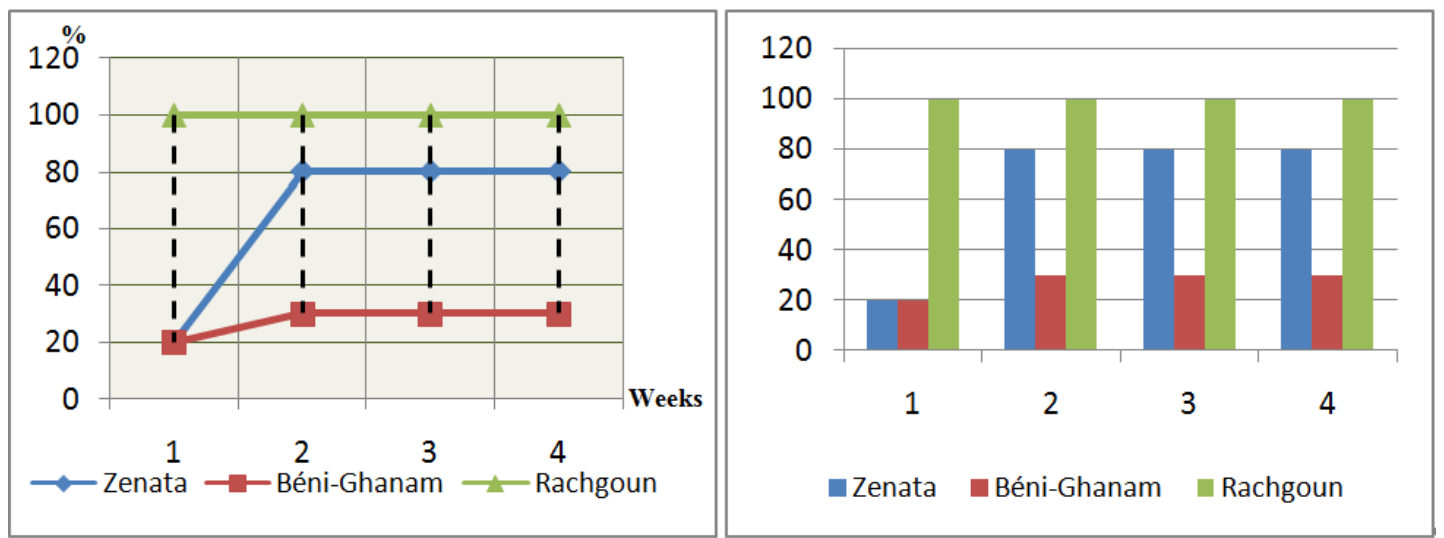

Figures 15. Number of germinated seeds in a medium with a $5 \mathrm{~g} / \mathrm{L}$ salt concentration ( $\mathrm{NaCl}$ ) at cold temperature $\left(4^{\circ} \mathrm{C}\right)$.

Seed germination in a medium with a $5 \mathrm{~g} / \mathrm{L}$ salt concentration $(\mathrm{NaCl})$ at cold temperature $\left(4^{\circ} \mathrm{C}\right)$ leads us to notice:

- Zenata station: during the 2 nd week we had a sudden sprouting at $80 \%$ which remained steady at this level until the end of the experiment.

- Beni-Ghanam station: during the first week there was a germination at $20 \%$, which rose and remained steady at $30 \%$ until the end of the experiment.

- Rachgoun station: we have an excellent seeds response, to the point that we recorded a total germination (100\%), representing a spectacular start of the germination.

\section{Conclusion}

Regarding this vegetative stage; it is a phenological stage in the life of plants (Sinapis arvensis germination seeds). To study this phenomenon we used two artificial media (Nutrient Agar and Potatoes Dextrose Agar) as well as distilled water to which we added different concentrations of $\mathrm{NaCl}(1 \mathrm{~g} / \mathrm{L}$ to $5 \mathrm{~g} / \mathrm{L})$.

From the results obtained, the temperature has a significantly effect on this phenomenon; germination remains possible while the cold $\left(4^{\circ} \mathrm{C}\right)$ inhibits the germination in an agar medium.

However, one must note that the germination conditions procedure was respected; microbial proliferation has not been too expressed.

As recommendations in the laboratory work, germination tests should be performed in maintaining well-defined conditions, because the presence of a single bacterium or fungus can trigger an invasion of the culture medium. That is why it is better to respect the rules, even simplify them. It would be necessary to ensure that all sterilized instruments are deposited in the sterile area, so as to have the slightest thing to do during handling and in sterile air

\section{References}

[1] Abdeljalil A., 2014 - Quelques aspects germinatifs, rhizogéniques et écologiques chez Sinapis arvensis L. dans la région de Tlemcen. Mém. Mast. Ecol. Univ. Tlemcen, 139 p.
[2] Augé R., Beauchesne G., Boccon-Gibod J., Decourtye L., Digat B., Jalouzot R., Minier R., Morand J .,Reynoird J. et Strullu D.,1989 - La culture in vitro et ses applications horticoles. $3^{\text {ème }}$ édition revue, corrigée et augmentée. Ed Tech. Doc. Lavoisier 225 p.

[3] Benchenfi Lachachi S., Benabadji N., Benmansour D., 2013 Contribution to the study of Lygeum spartum L. germinative hospeties in the south region of Tlemcen (Western Algeria).Environment Reserch Journal 7(2) ISSN 1994-5396: 20-24.

[4] Boccon-Gibod J., 1984 - Régénération du Crosne du Japon (Stachys sieboldii Mig.) par culture de méristème : multiplication et conservation in vitro des clones. In : Congrès sur l'application de la culture in vitro à l'amélioration desplantes potagères. EUCARPIA, section légumes, Versailles. 31- 41 .

[5] Dubey P.S and Mall L.P., 1972 - Ecology of germination of weed seeds. I. Role of temperature and depth of burial in soi. Oecologia, 10: 105-110.

[6] Haicour R., 2002 - Biotechnologie végétale : technique de laboratoire. Ed Tec et Doc. Montréal. AUF, 2002 (université francophones ISBN 2-7430-0560-2). 275p.

[7] Haines H., 1995 - The ecology of running waters. Liverpool University Press, Liverpool. 555p.

[8] Harper J.L and Benton R.A., 1966 - The behavior of seeds in soil. II. The germination of seeds on the surface of water supplying substrate. J. Ecol. 54: 151-166.

[9] Hebert Y., Lefort-Buson M. et Damaerval M., 1993 - Les outils d'évaluation de la diversité génétique. Agronomie. 8(3): 173-178.

[10] Heller, 1990 - Physiologie végétale et développement $4{ }^{\text {ème }}$ Éd. Mass. Et Cie, 270p.

[11] Jay Allmand C., Capelli P. and CornuD., 1992 - Root development of in vitro hybrid walnut microcutting in vermiculite containing gelrite medium. Station d'amélioration des arbres forestiers. INRA, 45160. Ardon France. ScienCIA horticultura. 51(3-4) : 335-342.

[12] Jay Allmand C. et Capelli P., 1997-La multiplication végétative in-vitro, base méthodologique. D. E. A. Ressources génétiques et Amélioration des plantes. INA Paris Grignon. $101 \mathrm{p}$. 
[13] Koller D and Hadas Y, 1982 - Water relations in the germination of seeds. In: Lange O.I., Osmond C.B and Ziegler $\mathrm{H}$ (Eds.) Encyclopedia of plant physiology. Springer-Verlag, Berlin. 12(B): 401-431.

[14] Loukidi N., 1998 - Contribution à une étude morphohistométrique de Malva sylvestris L. dans la région de Tlemcen. Mém. DES Physio. Vég. Univ. Tlemcen, 120p.

[15] Margara F., 1989 - Bases de multiplication végétative : les méristèmes et l'organogénèse. Ed INRA, Paris.262p.
[16] Ungar I. A., 1978- Halophyte seed germination. Bot. Rev., 44.233-264.

[17] Van Der Toorn J. and Ten Hove H. J., 1982 - On the ecology of Cotula coronopifolia L. and Ranunculus sceleratus L. II. Experiments on germination, seed longevity, and seedling survival. Acta ๕cologica. ๓col.Plant.Vol. 3 (17), nº 4. 409-418. 